\title{
ANALISIS PERBEDAAN ABNORMAL RETURN DAN TRADING VOLUME ACTIVITY SAHAM SEBELUM DAN SESUDAH PERISTIWA GEMPA DI YOGYAKARTA TANGGAL 27 MEI 2006 \\ (Sudi Kasus pada Perusahaan Asuransi Terdaftar di Bursa Efek Jakarta)
}

\author{
Oleh: \\ Lulu Nurul Istanti *)
}

\begin{abstract}
This research presents an empirical analysis of difference between abnormal return and trading volume activity before and after earths-quake, in Yogyakarta at May 27, 2006. And examine its statistical properties. This research argues that there was difference between abnormal return and trading volume activity before and after quake. For this purpose, the mean difference test, using t-test, was applied to compare the mean value of abnormal return and trading volume activity before and after quake. The sample of this research consists of the insurance firms listed at the Jakarta Stock Exchange. Investigation on the sample firms involved periods of ten days before quake and ten days after quake.

The results of this research indicate that there was no significant difference between the abnormal return and trading volume activity before and after quake. This evidence confirms that even did not positively influence abnormal return and trading volume activity as suggested theoretically.
\end{abstract}

Key words: return, trading volume activity (TVA), even study.

\section{PENDAHULUAN}

\section{Latar Belakang}

Pasar modal memiliki peranan penting bagi perekonomian suatu negara karena selain menjalankan fungsi ekonomi pasar modal juga menjalankan fungsi keuangan. Pasar modal dikatakan menjalankan fungsi ekonomi karena pasar modal menyediakan fasilitas untuk mempertemukan dua kepentingan sekaligus yaitu orang yang kelebihan dana (investor) dan orang yang membutuhkan dana (issuer). Pasar modal dikatakan menjalankan fungsi keuangan karena pasar modal memberikan kesempatan bagi pemilik dana untuk memperoleh keuntungan (return). Pasar modal yang terbesar di Indonesia adalah Bursa Efek Jakarta (BEJ) yang juga dikenal dengan nama asingnya sebagai Jakarta Stock Exchange (JSX). Sekuritas yang di perdagangkan di BEJ antara lain saham preferen (preferred stock), saham biasa (common stock), hak (rights) dan obligasi konvertibel (convertible bonds).

Dengan adanya pasar modal diharapkan aktivitas perekonomian menjadi meningkat. Karena pasar modal merupakan alternatif pendanaan bagi perusahaan- 
perusahaan, sehingga perusahaan dapat beroperasi dengan skala yang lebih besar yang nantinya dapat meningkatkan keuntungan perusahaan dan kemakmuran masyarakat luas. Pada dasarnya pasar modal merupakan pasar untuk berbagai instrumen keuangan jangka panjang baik dalam bentuk utang maupun modal sendiri. Seperti halnya pasar pada umumnya, pasar modal merupakan tempat bertemu antara pembeli dan penjual dengan risiko untung dan rugi. Untuk menarik para investor, maka pasar modal harus bersifat likuid dan efisien. Suatu pasar modal dikatakan likuid jika pembeli dan penjual dapat membeli maupun menjual surat-surat berharga dengan cepat. Pasar modal dikatakan efisien jika harga dari surat-surat berharga mencerminkan nilai dari perusahaan secara akurat (Jogianto,2000:12). Menurut Husnan (2001:8), bahwa keberhasilan pasar modal dipengaruhi oleh berbagai faktor diantaranya adalah supply dan demand sekuritas, kondisi politik dan ekonomi, masalah hukum dan peraturan serta keberadaan lembaga yang mengatur sekaligus mengawasi kegiatan pasar modal dan berbagai lembaga yang memungkinkan dilakukan transaksi secara efisien

Dalam berinvestasi di pasar modal tentunya para investor mengharapkan adanya suatu keuntungan yang disebut dengan return. Investasi dalam bentuk saham misalnya, seorang investor selain ingin mendapatkan dividen juga berharap untuk mendapatkan capital gain. Dividen merupakan pembagian keuntungan yang diberikan perusahaan penerbit saham atas keuntungan yang dihasilkan perusahaan. Capital gain merupakan selisih antara harga beli saham dengan harga jual saham. Apabila dengan terjadinya gempa di Yogyakarta 27 Mei 2006 membuat masyarakat sadar akan pentingnya asuransi maka investor saham perusahaan asuransi akan mendapatkan capital gain.

Abnormal return merupakan selisih antara return sesungguhnya dengan return yang diharapkan. Perhitungan abnormal return berguna dalam menguji efisiensi pasar dan kandungan informasi dari suatu pengumuman atau peristiwa. Suatu pengumuman atau peristiwa yang mengandung informasi akan memberikan abnormal return (AR) kepada pasar, dan sebaliknya yang tidak mengandung informasi tidak memberikan abnormal return (AR) kepada pasar. Jadi jika peristiwa gempa di Yogyakarta 27 Mei 2006 dianggap mengandung informasi maka investor saham perusahaan asuransi akan mendapatkan abnormal return. 
Salah satu indikator untuk mempelajari prilaku investor dalam perdagangan saham adalah dengan melihat pola perubahan volume perdagangan saham. Husnan (2001:350) mengatakan volume perdagangan (trading volume activity) merupakan salah satu indikator atau tanda untuk menentukan kapan akan membeli atau menjual saham. Jika volume perdagangan (trading volume activity) setelah terjadinya gempa di Yogyakarta 27 Mei 2006 meningkat maka mengindikasikan bahwa pasar modal dalam keadaan bullish, dalam kondisi seperti ini investor lebih baik membeli saham. Sebaliknya jika volume perdagangan setelah terjadinya gempa di Jogjakarta 27 Mei 2006 menurun maka pasar modal Indonesia dikatakan dalam keadaan bearish, sehingga dalam kondisi seperti ini investor lebih cocok untuk menjual saham yang dimilikinya.

Dalam situasi negara yang penuh risiko dan suhu politik yang cukup memanas di tambah bencana alam seperti peristiwa gempa di Yogyakarta 27 Mei 2006. Peristiwa tersebut menyebabkan banyak korban meninggal dunia dan luka-luka ditambah dengan rusaknya infrastruktur dan bangunan sehingga menyebabkan aktivitas perekonomian terganggu. Dengan adanya gempa di Yogyakarta diharapkan masyarakat sadar akan pentingnya asuransi dan berbondong-bondong mengasuransikan harta bendanya bahkan jiwanya untuk diasuransikan demi menjaga suatu kerugian yang tidak pasti. Banyaknya masyarakat yang mengasuransikan harta bendanya akan membuat perusahaan asuransi menjadi lebih berkembang dan akan menarik jumlah permintaan saham perusahaan asuransi yang akan ditunjukkan dengan adanya perubahan pada return dan trading volume activity.

\section{Rumusan Masalah}

1. Apakah terdapat perbedaan yang signifikan antara abnormal return saham sebelum dan sesudah terjadinya gempa di Yogyakarta 27 Mei 2006

2. Apakah terdapat perbedaan yang signifikan antara rata-rata trading volume activity saham sebelum dan sesudah terjadinya gempa di Yogyakarta 27 Mei 2006?

\section{Tujuan}

1. Untuk menhetahui apakah terdapat perbedaaan antara abnormal return saham sebelum dan sesudah terjadinya gempa di Yogyakarta 27 Mei 2006 
2. Untuk mengetahui apakah terdapat perbedaaan antara rata-rata trading volume activity saham sebelum dan sesudah terjadinya gempa di Yogyakarta 27 Mei 2006.

\section{KAJIAN PUSTAKA}

\section{Faktor-Faktor yang Mempengaruhi Pasar Modal}

Menurut Husnan (2001:8) keberhasilan pasar modal dipengaruhi supply dan demand. Secara rincinya pasar modal dipengaruhi faktor-faktor sebagai berikut:

1) Supply sekuritas

Faktor ini berarti harus banyak perusahaan emiten yang tersedia untuk menerbitkan sekuritas di pasar modal.

2) Demand sekuritas

Dalam hal ini harus terdapat anggota masyarakat yang memiliki jumlah dana yang cukup besar untuk digunakan membeli sekuritas-sekuritas yang ditawarkan. Calon pembeli sekuritas tersebut bisa dari individu, perusahaan non keuangan maupun lembaga-lembaga keuangan. Hal ini berarti income per capita suatu negara dan distribusi pendapatan mempengaruhi besar kecilnya permintaan akan sekuritas.

3) Kondisi politik dan ekonomi

Kondisi politik yang stabil akan mendukung pertumbuhan ekonomi yang pada akhirnya akan mempengaruhi supply dan demand akan sekuritas.

4) Masalah hukum dan peraturan

Pembeli sekuritas pada dasarnya mengandalkan peran informasi yang disediakan oleh perusahaan-perusahaan penerbit sekuritas. Kebenaran informasi tersebut sangat penting, disamping kecepatan dan kelengkapan informasi. Peraturan yang melidungi pemodal dari informasi yang tidak benar dan menyesatkan juga mutlak diperlukan.

5) Keberadaan lembaga yang mengatur dan mengawasi kegiatan pasar modal dan berbagai lembaga yang memungkinkan dilakukan transaksi secara efisien.

Kegiatan di pasar modal pada dasarnya merupakan kegiatan yang dilakukan oleh pemilik dana dan pihak yang memerlukan dana secara langsung. Maka dari itu peran informasi yang dapat diandalkan kebenarannya serta kecepatan dan kelengkapannya menjadi sangat penting. Agar taransaksi dapat dilakukan secara 
efisien maka diperlukan berbagai lembaga dan profesi yang menjamin persyaratanpersyaratan tersebut dipenuhi.

\section{Pasar Modal yang Efisien}

Menurut Husnan (2001) pasar modal yang efisien adalah pasar yang harga sekurutas-sekuritasnya mencerminkan semua informasi yang relevan. Suatu informasi di anggap relevan bilamana informasi tersebut dapat membuat pasar modal bereaksi yang mana semakin cepat informasi tersebut tercermin pada sekuritas maka pasar modal tersebut semakin efisisen.

Menurut Jogianto (2000) ada 3 bentuk efisiensi pasar modal berdasarkan informasi yamg tersedia, yaitu :

1. Efisiensi pasar bentuk lemah (weak form)

Pada pasar dengan bentuk lemah, harga-harga sekuritas yang terjadi pada saat ini merupakan pencerminan secara penuh informasi masa lalu. Dalam pasar efisien bentuk lemah, nilai-nilai masa lalu tidak dapat digunakan untuk memprediksi harga sekarang. Dalam hal ini berarti investor tidak dapat menggunakan informasi masa lalu untuk memperoleh keuntungan tidak normal (abnormal return).

2. Efisiensi pasar bentuk setengah kuat (semi strong form)

Pasar dikatakan dalam bentuk setengah kuat jika harga-harga sekuritas secara penuh mencerminkan semua informasi yang dipublikasikan Dalam pasar seperti ini harga yang terjadi adalah harga yang wajar.

3. Efisiensi pasar bentuk kuat (strong form)

Pasar dikatakan efisien dalam bentuk kuat jika harga-harga sekuritas secara penuh mencerminkan semua informasi yang tersedia termasuk informasi yang privat. Dalam pasar bentuk ini, tidak ada investor yang dapat memperoleh keuntungan tidak normal karena mempunyai informasi privat.

Fama (1970) dalam Jogiyanto (2000:397) membagi pengujian efisiensi pasar menjadi tiga kategori yang dihubungkan dengan bentuk-bentuk efisiensi pasarnya sebagai berikut:

(1) Pengujian-pengujian untuk bentuk lemah (weak-form tests), yaitu seberapa kuat informasi masa lalu dapat memprediksi masa depan. 
(2) Pengujian-pengujian bentuk setengah kuat (semi- strong-form tests), yaitu seberapa cepat harga sekuritas merefleksikan informasi yang dipublikasikan.

(3) Pengujian-pengujian bentuk kuat (strong-form tests), yaitu untuk menjawab pertanyaan apakah investor mempunyai informasi privat yang tidak terefleksi di harga sekuritas.

Selanjutnya Fama (1991) dalam Jogiyanto (2000:398) merubah nama ketiga macam kategori pengujian efisiensi pasar tersebut. Nama-nama pengujian yang diusulkan adalah sebagai berikut.

(1) Pengujian-pengujian efisiensi pasar bentuk lemah diganti menjadi pengujian terhadap pendugaan return (tests for return predictability).

(2) Pengujian-pengujian efisiensi pasar bentuk setengah kuat diubah menjadi studistudi peristiwa (event study).

(3) Pengujian-pengujian efisiensi pasar bentuk kuat diusulkan menjadi pengujianpengujian terhadap informasi privat (test for private information)

\section{Abnormal Return}

Menurt Jogiyanto (2000) abnormal return merupakan selisih antara return sesungguhnya yang terjadi dengan return ekspektasi Sedangkan menurut Husnan (2001:274) abnormal return adalah selisih antara tingkat keuntungan yang sebenarnya yang diperoleh investor, yang dihitung dengan menggunakan model tertentu. Adapun rumus dari abnormal return yaitu sebagai berikut :

$$
A R_{i t}=R_{i t}-E\left(R_{i t}\right)
$$

Keterangan:

$\mathrm{AR}_{\mathrm{it}}=$ abnormal return saham $\mathrm{i}$ pada periode $\mathrm{t}$

$\mathrm{R}_{\mathrm{it}} \quad=$ actual return saham $\mathrm{i}$ pada periode $\mathrm{t}$

$\mathrm{E}\left(\mathrm{R}_{\mathrm{it}}\right)=$ expected return saham $\mathrm{i}$ pada periode $\mathrm{t}$

Menurut Brown dan Warmer (1985) dalam Jogiyanto (2000:416) return yang diharapkan (expected return) dapat dicari dengan tiga model, yaitu: mean adjusted model, market model dan market adjusted model. Sedangkan dalam penelitian ini digunakan market adjusted model dalam menghitung return yang diharapkan (expected return), yaitu return yang diharapkan (expected return) semua sekuritas sama dengan return pasarnya, (Jogiyanto, 2000:445) dimana return pasar dapat dicari dengan formula: 


$$
R_{m t}=\frac{I H S G_{t}-I H S G_{t-1}}{I H S G_{t-1}}
$$

(Jogiyanto,2000)

dimana:

$\mathrm{R}_{\mathrm{mt}} \quad=$ return pasar pada periode $\mathrm{t}$

$\mathrm{IHSG}_{\mathrm{t}}=$ indeks harga saham gabungan pada periode ke $\mathrm{t}$

$\mathrm{IHSG}_{\mathrm{t}-1}=$ indeks harga saham gabungan pada periode ke $\mathrm{t}-1$

\section{Trading Volume Activity (TVA)}

Salah satu indikator untuk mempelajari prilaku investor dalam perdagangan saham adalah dengan melihat pola perubahan volume perdagangan saham atau yang disebut Trading volume activity. Dalam melakukan perdagangan saham digunakan dua analisis, yaitu analisis teknikal dan analisi fundamental. Menurut Husnan (2001) , analisis fundamental merupakan analisis dengan melihat prospek-prospek perusahaan (dengan mengidentifikasi faktor-faktor yang mempengaruhi) untuk memperkirakan harga sekurita di masa yang akan datang. Sedangkan analisis teknikal merupakan analisis dengan melihat pergerakan harga saham di masa lalu untuk memperkirakan harga sekuritas di masa yang akan datang.

Trading volume activity merupakan instrumen yang dapat digunakan untuk melihat reaksi pasar modal terhadap informasi melalui pergerakan aktivitas volume perdagangan saham di pasar (Suryawijaya,1998). Trading volume activity (aktivitas volume perdagangan saham) dapat dihitung dengan membandingkan jumlah saham perusahaan yang diperdagangkan dalam suatu periode tertentu dengan keseluruhan saham jumlah saham yang beredar dari perusahaan tersebut pada kurun waktu yang sama. Menurut Suryawijaya (1998:145) formulasi perhitungan trading volume activity (TVA) saham adalah sebagai berikut:

$$
\mathrm{TVA}_{\mathrm{it}}=\frac{\sum \text { saham i ditransaksikanwaktu t }}{\sum \text { sahamiberedar waktu } t} \quad \text { (Suryawijaya, 1998) }
$$

Keterangan:

$\mathrm{TVA}_{\mathrm{it}}=$ Trading volume activity saham i pada periode $\mathrm{t}$. 


\section{Event Study (Studi Peristiwa)}

Event study adalah suatu pengamatan mengenai pergerakan harga saham di pasar modal untuk mengetahui apakah ada abnormal return yang diperoleh pemegang saham akibat dari suatu peristiwa tertentu (Peterson dalam Suryawijaya, 1998). Menurut Jogiyanto (2000) event study merupakan studi yang mempelajari reaksi pasar modal terhadap peristiwa (event) yang informasinya dipublikasikan sebagai pengumuman dan dapat juga digunakan untuk menguji efisiensi pasar bentuk setengah kuat. Dari pengertian di atas event study berguna untuk menguji efisiensi pasar modal setengah kuat, apakah muatan informasi sebuah peristiwa berpengaruh atau terefleksi di dalam pasar modal secara benar.

\section{METODOLOGI}

Variabel yang digunakan dalam penelitian ini adalah abnormal return dan trading volume activity (TVA) saham. Penelitian ini merupakan penelitian dengan pendekatan kuantitatif, yaitu mengumpulkan, mengolah, menyederhanakan, menyajikan, dan menganalisa data agar dapat memberikan gambaran yang teratur tentang suatu peristiwa dengan observasi yang dinyatakan dengan angka-angka.

Penelitian ini membandingkan abnormal return dan trading volume activity (TVA) saham perusahaan asuransi sebelum dan sesudah terjadinya peristiwa gempa di Yogyakarta tanggal 27 Mei 2006 selama 20 hari bursa, yaitu 10 hari sebelum dan 10 hari setelah terjadinya peristiwa. Periode penelitian dilakukam selama 20 hari karena peristiwa ini merupakan peristiwa yang nilai ekonomisnya sulit ditentukan oleh investor dimana investor memerlukan cukup waktu lama untuk bereaksi terhadap peristiwa tersebut. Periode waktu penelitian da pat digambarkan sebagai berikut:

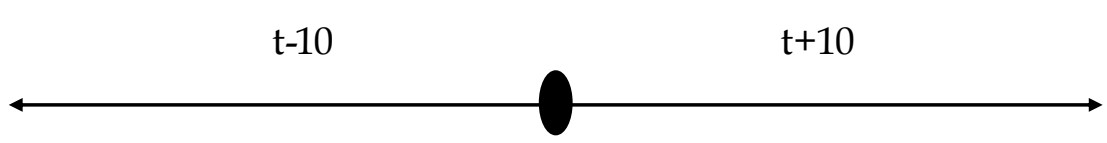

27 Mei 2006

Perusahaan yang dijadikan obyek penelitian adalah perusahaan asuransi yang terdaftar di Bursa Efek Jakarta. Data penelitian diperoleh dari dua studi, yang pertama 
adalah studi literatur yang dilakukan untuk memberi gambaran teoritis yang mendukung kerangka berfikir dan hipotetis. Yang kedua adalah studi lapangan yang bertujuan untuk mendapatkan data yang berguna untuk menguji dan menganalisis perbedaan return dan trading volume activity (TVA) saham perusahaan asuransi sebelum dan sesudah terjadinya peristiwa gempa di Yogyakarta 27 Mei 2006.

Adapun sampel dalam penelitian ini adalah sebagai berikut:

1 Asuransi Harta Aman P Tbk

2 Asuransi Bina Dana Arata Tbk

3 Asuransi Bintang Tbk

4 Asuransi Dayin MitraTbk

5 Asuransi Jasa Tania Tbk

6 Asuransi Multi Artha Guna Tbk

7 Asuransi Ramayana Tbk

8 Lippo E-NET Tbk

9 Lippo General Insurance Tbk

10 Maskapai Reasuransi Ind. Tbk

11 Panin Insurance Tbk

12 Panin Life Tbk

13 Perusahaan Gas Negara Tbk

14 Pool Advista Indonesia Tbk

15 Samudera Indonesia Tbk

Penelitian ini menggunakan data sekunder. Data sekunder adalah data yang diperoleh tidak dari sumbernya langsung melainkan sudah dikumpulkan oleh pihak lain yang sudah diolah dan biasanya dalam bentuk publikasi dan jurnal. Data skunder yang digunakan dalam penelitian ini adalah data harga saham harian, jumlah saham yang beredar, jumlah saham yang diperdagangkan dan IHSG selama periode penelitian yang diperoleh melalui situs www.jsx.co.id dan www.E-bursa.com. Dimana harga saham harian diolah menjadi abnormal return saham, sedangkan jumlah saham yang beredar dan jumlah saham yang ditransaksikan akan diolah menjadi trading volume activity saham.

Hipotesis dalam penelitian ini adalah: 
1. Diduga terdapat perbedaan yang signifikan pada abnormal return saham sebelum dan sesudah terjadinya gempa di Yogyakarta 27 Mei 2006.

2. Diduga terdapat perbedaan yang signifikan pada rata-rata trading volume activity saham sebelum dan sesudah terjadinya gempa di Yogyakarta 27 Mei 2006.

Langkah-langkah yang dilakukan dalam pengujian hipotesis adalah sebagai berikut:

\section{Hipotesis Pertama}

Langkah-langakah yang dijalankan untuk melakukan pengujian adalah:

a. Menyimpulkan Hipotesis

$\mathrm{H}_{0}$ : Tidak ada perbedaan signifikan antara rata-rata abnormal return saham sebelum dan sesudah peristiwa gempa di yogyakarta. 27 Mei 2006

$\mathrm{H}_{1}$ : Ada perbedaan signifikan antara rata-rata abnormal return saham sebelum dan sesudah peristiwa gempa di yogyakarta. 27 Mei 2006

b. Menghitung return saham individual pada hari ke-t

$$
R_{i t}=\frac{P_{i t}-P_{i t-1}}{P_{i t-1}}
$$

Keterangan:

$\mathrm{R}_{\mathrm{it}}=$ return saham individual i pada periode $\mathrm{t}$

$P_{i t}=$ harga saham individual i pada periode $t$

$\mathrm{R}_{\mathrm{it}}=$ harga saham individual i pada periode $\mathrm{t}-1$

c. Menghitung Return Pasar

$$
R_{m t}=\frac{I H S G_{t}-I H S G_{t-1}}{I H S G_{t-1}}
$$

Keterangan:

$R_{m t} \quad=$ Return indeks pasar

$\mathrm{IHSG}_{\mathrm{t}}=$ Indeks Harga Saham Gabungan pada periode $\mathrm{t}$

$\mathrm{IHSG}_{\mathrm{t}-1}=$ Indeks Harga Saham Gabungan pada periode $\mathrm{t}_{-1}$

d. Menghitung Abnormal return

$$
A R_{i t}=R_{i t}-E\left(R_{i t}\right)
$$

Keterangan:

$$
\begin{array}{ll}
\mathrm{AR}_{\mathrm{it}} & =\text { Abnormal Return } \\
\mathrm{R}_{\mathrm{it}} & =\text { Return actual } \\
\mathrm{E}\left(\mathrm{R}_{\mathrm{it}}\right) & =\text { expected return }
\end{array}
$$


e. Menghitung rata-rata abnormal return sebelum dan sesudah peristiwa gempa di yogyakarta. 27 Mei 2006

$$
\begin{aligned}
& \overline{A R}_{\text {sebelum }}=\frac{\sum A R_{\text {sebelum }}}{t} \\
& \overline{A R}_{\text {sesudah }}=\frac{\sum A R_{\text {sesudah }}}{t}
\end{aligned}
$$

Keterangan:

$\overline{A R} \quad=$ Rata-rata abnormal return

$\mathrm{T} \quad=$ Periode waktu

f. Pengujian statistik

Pengujian statistik dilakukan dengan menggunakan program komputer SPSS for Windows Vertion 13.0. untuk mengetahui data itu berdistribusi normal atau tidak maka dilakukan uji normalitas terlebih dahulu. Apabila data berdistribusi normal digunakan teknik statistik uji rata-rata dari dua kelompok sampel yang berpasangan (Paired Two Sample for Means test). Uji t digunakan jika dilakukan analisis dua sampel berpasangan dengan taraf signifikan sebesar $5 \%(\alpha=0,05)$. Apabila data berdistribusi tidak normal digunakan teknik analisis statistik non parametrik Wilcoxon Signed Ranks Test dengan taraf signifikan sebesar 5\% ( $\alpha=$ $0,05)$.

g. Kesimpulan

Jika probabilitas $\mathrm{t}>0,05$ maka $\mathrm{H}_{0}$ diterima

Jika probabilitas $\mathrm{t}<0,05$ maka $\mathrm{H}_{0}$ ditolak.

\section{Hipotesis Kedua}

$\mathrm{H}_{0}$ : Tidak ada perbedaan signifikan antara rata-rata tranding volume activity saham sebelum dan sesudah peristiwa gempa di Yogyakarta 27 Mei 2006.

$\mathrm{H}_{1}$ : Ada perbedaan signifikan antara rata-rata tranding volume activity saham sebelum dan sesudah peristiwa gempa di Yogyakarta 27 Mei 2006.

Langkah-langkah yang dilakukan:

a. Menghitung trading volume activity (TVA) saham pada periode $\mathrm{t}$ : 
$T V A=$ jumlah saham yang diperdagangkan pada waktu t

(Subagyo, 2005) jumlah saham yang beredar pada waktu $t$

b. Menghitung rata-rata tranding volume activity (TVA) sebelum dan sesudah

$$
\frac{\sum T V A_{\text {sebelum }}}{t}
$$

(Subagyo, 2005)

$$
\frac{\sum T V A_{\text {sesudah }}}{T V A_{\text {sesudah }}}
$$

Keterangan:

$\overline{T V A}=$ Rata-rata abnormal return

c. Pengujian statistik

Pengujian statistik dilakukan dengan menggunakan program komputer SPSS for Windows Vertion 13.0, untuk mengetahui data itu berdistribusi normal atau tidak maka dilakukan uji normalitas terlebih dahulu. Apabila data berdistribusi normal digunakan teknik statistik uji rata-rata dari dua kelompok sampel yang berpasangan (paired Two Sample For Means test). Uji t digunakan jika dilakukan analisis dua sampel berpasangan dengan taraf signifikan sebesar $5 \%(\alpha=0,05)$. A pabila data berdistribusi tidak normal digunakan teknik analisis statistik non parametrik Wilcoxon Signed Ranks Test dengan taraf signifikan sebesar 5\% ( $\alpha=$ $0,05)$.

d. Kesimpulan

Jika probabilitas $\mathrm{t}>0,05$ maka $\mathrm{H}_{0}$ diterima

Jika probabilitas $\mathrm{t}<0,05$ maka $\mathrm{H}_{0}$ ditolak

\section{HASIL}

\section{Pengujian Hipotesis Pertama}

Abnormal return merupakan selisih antara harga saham yang sebenarnya dengan harga saham yang diharapkan. Abnormal return digunakan untuk menguji efisiensi pasar dan kandungan inforamasi dari suatu pengumuman atau peristiwa. Suatu pengumuman atau peristiwa yang mengandung informasi akan memberikan abnormal return (AR) kepada pasar, dan sebaliknya yang tidak mengandung informasi 
tidak memberikan abnormal return (AR) kepada pasar. Berikut di sajikan perhitungan rata-rata abnormal return saham perusahaan asuransi sebelum dan sesudah terjadinya gempa di Yogyakarta 27 Mei 2006.

Tabel 1. Rata-rata Abnormal Return Saham Harian Perusahaan Asuransi Sebelum dan Sesudah Peristiwa Gempa di Yogyakarta 27 Mei 2006

\begin{tabular}{|l|l|l|l|}
\hline Periode & \multicolumn{1}{|c|}{ Rata-rata AR sebelum } & Periode & Rata-rata AR sesudah \\
\hline $\mathrm{t}-10$ & 0.00285000 & $\mathrm{t}+1$ & -0.00449000 \\
\hline $\mathrm{t}-9$ & 0.01221000 & $\mathrm{t}+2$ & -0.01782000 \\
\hline $\mathrm{t}-8$ & 0.03650000 & $\mathrm{t}+3$ & 0.02322000 \\
\hline $\mathrm{t}-7$ & -0.02412000 & $\mathrm{t}+4$ & -0.01300000 \\
\hline $\mathrm{t}-6$ & -0.00473000 & $\mathrm{t}+5$ & -0.01863000 \\
\hline $\mathrm{t}-5$ & 0.02342000 & $\mathrm{t}+6$ & -0.01628000 \\
\hline $\mathrm{t}-4$ & 0.00978000 & $\mathrm{t}+7$ & 0.04069000 \\
\hline $\mathrm{t}-3$ & 0.03216000 & $\mathrm{t}+8$ & 0.04180000 \\
\hline $\mathrm{t}-2$ & -0.01879000 & $\mathrm{t}+9$ & 0.01220000 \\
\hline $\mathrm{t}-1$ & 0.01585000 & $\mathrm{t}+10$ & -0.00720000 \\
\hline
\end{tabular}

(Sumber: Data diolah)

Berdasarkan tabel 1 untuk mengetahui lebih jelas pergerakan rata-rata abnormal return sebelum dan sesudah terjadinya gempa di Yogyakarta 27 Mei 2006 dapat di gambarkan dalam bentuk grafik sebagai berikut:

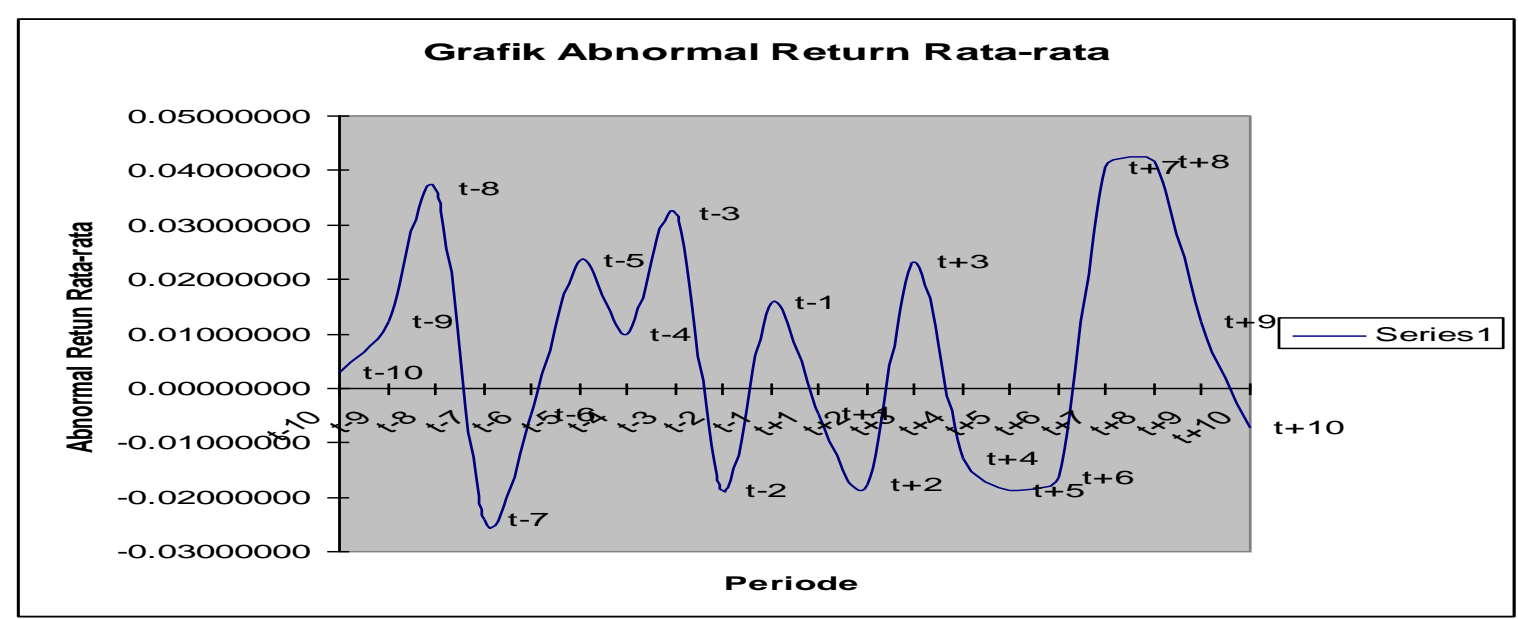

Gambar 1. Pergerakan Rata-rata Abnormal Return Saham Harian Perusahaan Asuransi Sebelum dan Sesudah Peristiwa Gempa di Yogyakarta 27 Mei 2006 (Sumber: tabel 1)

Berdasarkan tabel 1 dan gambar 1 di atas maka dapat disimpulkan bahwa pada saat 10 hari sebelum terjadinya peristiwa gempa rata-rata abnormal return bergerak fluktuatif. Rata-rata abnormal return terendah dicapai pada saat t-7 yaitu dengan nilai rata-rata abnormal return sebesar -0.02412000 dan rata-rata abnormal return tertinggi sebelum terjadinya peristiwa gempa adalah pada saat t-8 yaitu dengan nilai rata-rata 
abnormal return sebesar 0.03650000 . Sedangkan rata-rata abnormal return 10 hari setelah terjadinya gempa di Yogyakarta juga bergerak secara fluktuatif. Rata-rata abnormal return terendah di capai pada saat $\mathrm{t}+5$ yaitu dengan nilai rata-rata abnormal return sebesar -0.01863000 dan rata-rata abnormal return tertinggi dicapai pada saat $\mathrm{t}+8$ yaitu dengan nilai rata-rata abnormal return sebesar 0.04180000 .

Berikut disajikan rata-rata abnormal return dan standar devisiasi saham perusahaan asuransi sebelum dan sesudah peristiwa gempa di Yogyakarta 27 Mei 2006.

Tabel 2. Rata-rata Abnormal Return dan Standar Deviasi Saham Perusahaan Asuransi Sebelum dan Sesudah Peristiwa Gempa di Yogyakarta 27 Mei 2006

\begin{tabular}{|c|c|c|}
\hline Periode & Mean & Standar Deviasi \\
\hline Sebelum & 0.00851300 & 0.020143 \\
Sesudah & 0.00404900 & 0.023799 \\
\hline
\end{tabular}

(Sumber: data diolah)

Dari tabel 2 dapat dilihat bahwa rata-rata abnormal return pada periode sebelum peristiwa adalah 0.00851300 dan periode sesudah peristiwa adalah 0.00404900 . Dengan kata lain bahwa rata-rata abnormal return. Pada periode sebelum peristiwa lebih tinggi jika dibandingkan sesudah peristiwa. Tetapi standar deviasi pada periode sesudah terjadinya peristiwa terlihat sedikit lebih tinggi jika dibandingkan pada periode sebelum terjadinya peristiwa yaitu dengan standar devisiasi sebesar 0.023799 pada periode sesudah peristiwa dan standar devisisasi sebesar 0.020143 pada periode sebelum peristiwa. Hal ini menunjukkan bahwa risiko pada peride sebelum peristiwa lebih rendah jika dibandingkan sesudah peristiwa.

Setelah dilakukan pengujian normalitas maka dilakukan pengujian hipotesis yaitu untuk mengetahui apakah peristiwa gempa di Yogyakartya pada tanggal 27 Mei 2006 dapat mempengaruhi saham perusahaan asuransi. Pengujian hipotesis dilakukan dengan menggunakan program SPSS yaitu statistik parametik "Paired Two Sample For Mean Test" (uji t), semua variabel diuji dengan menggunakan uji $t$ karena semuanya berdistribusi normal. Berikut hasil pengujian hipotesis pertama:

Tabel 3. Hasil Pengujian Hipotesis Rata-rata Abnormal Return Sebelun dan Sesudah Peristiwa Gempa di Yogyakarta 27 Mei 2006.

\begin{tabular}{|c|c|c|c|c|c|}
\hline Hipotesis & $\begin{array}{c}\text { Periode } \\
\text { pengamatan }\end{array}$ & t-hitung & 2-tail sig & signifikansi & hasil \\
\hline 1 & Before-after & 0,578 & 0,577 & Tidak signifikan & Ho di terima \\
\hline
\end{tabular}

(Sumber: data diolah) 
Berdasarkan pada tabel 3 dapat dilihat hasil pengujian statistik" Paired Two Sampel for Means" (uji t) rata-rata abnormal return saham perusahaan asuransi pada 10 hari dan 10 hari setelah terjadinya gempa di Yogyakarta 27 Mei 2006. Dari pengujian di peroleh hasil t-hitung sebesar 0,578 dan 2- tail sig. sebesar 0,577. Jadi dapat dikatakan bahwa nilai 2-tail sig > taraf signifikansi a $(0,05)$ dengan demikian dapat disimpulkan bahwa tidak ada perbedaan antara rata-rata abnormal return sebelum dengan rata-rata abnormal return sesudah peristiwa gempa di Yogyakarta 27 Mei 2006 atau dengan kata lain penerimaan Ho.

\section{Pengujian Hipotesis Kedua}

Trading volume activity merupakan salah satu indikator dalam mempelajari perilaku investor dalam perdagangan saham. Perhitungan trading volume activity yaitu dengan membandingkan jumlah saham yang ditransaksikan pada periode tertentu dengan jumlah saham yang beredar.

Berikut ini merupakan perhitungan rata-rata trading volume activity saham perusahaan asuransi 10 hari sebelum dan 10 hari setelah terjadinya gempa di Yogyakarta 27 Mei 2006.

Tabel 4. Rata-rata Trading Volume Activity Saham Harian Perusahaan Asuransi Sebelum dan Sesudah Peristiwa Gempa di Yogyakarta 27 Mei 2006

\begin{tabular}{|c|c|c|c|}
\hline Periode & Rata-rata TVA Sebelum & Periode & Rata-rata TVA Sesudah \\
\hline $\mathrm{t}-10$ & 0.00940467 & $\mathrm{t}+1$ & 0.00026938 \\
\hline $\mathrm{t}-9$ & 0.00115024 & $\mathrm{t}+2$ & 0.00164562 \\
\hline $\mathrm{t}-8$ & 0.00429480 & $\mathrm{t}+3$ & 0.00070096 \\
\hline $\mathrm{t}-7$ & 0.00241457 & $\mathrm{t}+4$ & 0.00598210 \\
\hline $\mathrm{t}-6$ & 0.00166926 & $\mathrm{t}+5$ & 0.00061132 \\
\hline $\mathrm{t}-5$ & 0.00114402 & $\mathrm{t}+6$ & 0.00041344 \\
\hline $\mathrm{t}-4$ & 0.00176095 & $\mathrm{t}+7$ & 0.00104834 \\
\hline $\mathrm{t}-3$ & 0.00142774 & $\mathrm{t}+8$ & 0.00032343 \\
\hline $\mathrm{t}-2$ & 0.00185509 & $\mathrm{t}+9$ & 0.00070159 \\
\hline $\mathrm{t}-1$ & 0.00079193 & $\mathrm{t}+10$ & 0.00277904 \\
\hline
\end{tabular}

(Sumber: data diolah)

Berdasarkan tabel 4 untuk mengetahui lebih jelas pergerakan rata-rata trading volume activity saham perusahaan asuransi sebelum dan sesudah terjadinya peristiwa gempa di Yogyakarta 27 Mei 2006 dapat digambarkan dalam bentuk grafik sebagai berikut: 


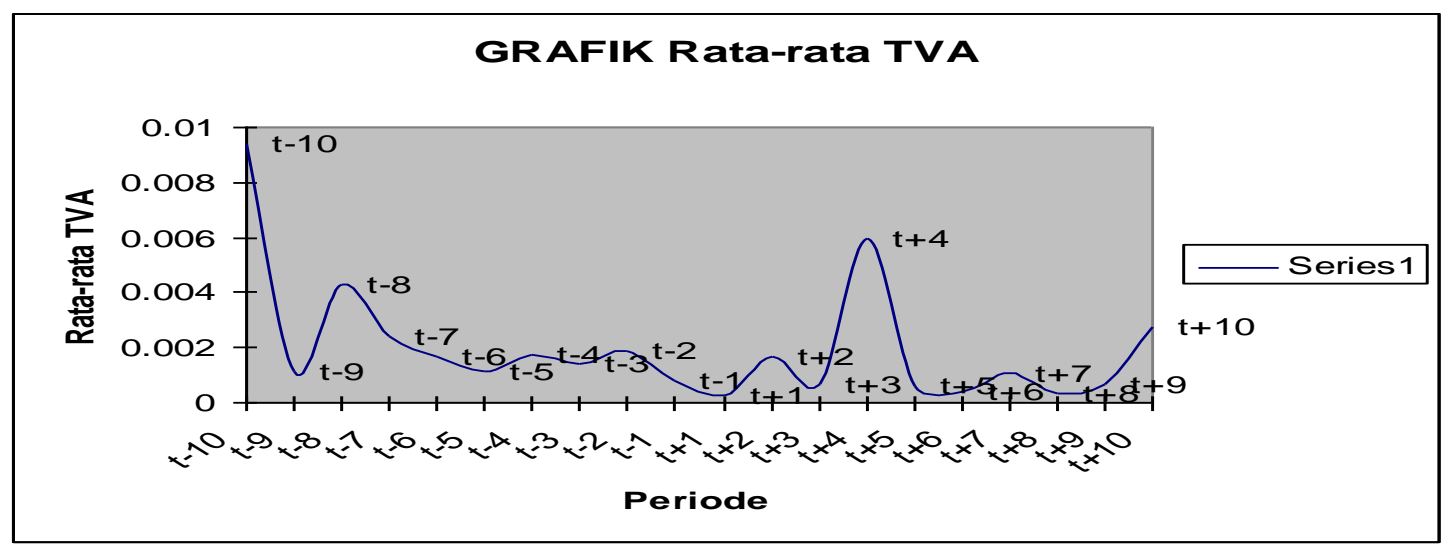

Gambar 2. Grafik rata-rata Trading Volume Activity Saham Harian Sebelum dan Sesudah Peristiwa (Sumber: tabel 4)

Dari gambar 2 dapat disimpulkan bahwa pergerakan rata-rata trading volume activity 10 sebelum terjadinya gempa di Yogyakarta 27 Mei 2006 adalah fluktuatif dimana rata-rata trading volume activity terendah dicapai pada saat $\mathrm{t}-1$ yaitu dengan nilai rata-rata trading volume activity sebesar 0.00079193 dan rata-rata trading volume activity tertinggi tercapai pada saat $\mathrm{t}-10$ yaitu dengan nilai rata-rata trading volume activity sebesar 0.00940467. Sedangkan rata-rata trading volume activity setelah peristiwa gempa di Yogyakarta 27 Mei 2006 juga bergerak fluktuatif dimana rata-rata trading volume activity terendah di capai pada saat $\mathrm{t}+1$ yaitu dengan nilai rata-rata trading volume activity sebesar 0.00026938 dan rata-rata trading volume activity tertinggi tercapai pada saat $\mathrm{t}+4$ yaitu dengan nilai rata-rata trading volume activity sebesar 0.00598210 .

Berikut ini adalah rata-rata trading volume activity dan standar devisiasi saham perusahaan asuransi sebelum dan sesudah peristiwa gempa di Yogyakarta 27 Mei 2006.

Tabel 5. Rata-rata Trading Volume Activity dan Standar Deviasi Saham Perusahaan Asuransi Sebelum dan Sesudah Terjadinya Peristiwa Gempa di Yogyakarta 27 Mei 2006

\begin{tabular}{|c|c|c|}
\hline Periode & Mean & Standar Deviasi \\
\hline Sebelum & 0.0025913 & 0.00258628 \\
Sesudah & 0.0014475 & 0.00176597 \\
\hline
\end{tabular}

(Sumber: data diolah)

Berdasarkan tabel 5 dapat menunjukkan bahwa rata-rata trading volume activity pada periode sebelum peristiwa terlihat lebih tinggi jika dibandingkam pada periode sesudah peristiwa. Pada periode sebelum peristiwa dan rata-rata trading volume activity sebesar 0.002591327 dan pada periode sesudah peristiwa sebesar 
0.001447522. Begitu juga dengan standar deviasi pada periode sebelum peristiwa juga lebih tinggi jika di bandingkan pada periode sesudah peristiwa. Pada periode sebelum peristiwa sebesar 0.002586282 dan pada periode sesudah peristiwa.sebesar 0.00176597 .

Setelah dilakukan pengujian normalitas maka dilakukan pengujian hipotesis yaitu untuk mengetahui apakah peristiwa gempa di Yogyakartya pada tanggal 27 Mei 2006 dapat mempengaruhi saham perusahaan asuransi. Pengujian hipotesis dilakukan dengan menggunakan program SPSS yaitu statistik parametik "Paired Two Sample For Mean Test" (uji t), semua variable diuji dengan menggunakan uji t karena semuanya berdistribusi normal. Berikut ini adalah hasil pengujian hipotesis kedua:

Tabel 6. Hasil Pengujian Hipotesis Rata-rata Trading Volume Activity (TVA)

Sebelun dan Sesudah Peristiwa Gempa di Yogyakarta 27 Mei 2006.

\begin{tabular}{|c|c|c|c|c|c|}
\hline Hipotesis & $\begin{array}{c}\text { Periode } \\
\text { pengamatan }\end{array}$ & t-hitung & 2-tail sig & signifikansi & hasil \\
\hline 2 & Before-after & 1,059 & 0,317 & $\begin{array}{c}\text { Tidak } \\
\text { signifikan }\end{array}$ & Ho diterima \\
\hline
\end{tabular}

(Sumber: data diolah)

Berdasarkan tabel 6 dapat dilihat hasil pengujian statistik“ Paired Two Sampel for Means" (uji t) rata-rata TVA saham perusahaan asuransi pada 10 hari dan 10 hari setelah terjadinya gempa di Yogyakarta 27 Mei 2006. Dari pengujian di peroleh hasil thitung sebesar 1,059 dan 2- tail sig. sebesar 0,317. Dengan demikian maka Ho diterima karena taraf signifikansi a $(0,05)<2$ - tail sig. Maka dapat dikatakan bahwa tidak ada perbedaan yang signifikan antara Trading volume activity (TVA) sebelum dengan Trading volume activity (TVA) sesudah peristiwa gempa di Yogyakarta 27 Mei 2006.

\section{PEMBAHASAN}

Perbedaan Abnormal Return Saham Sebelum dan Sesudah Peristiwa Gempa di Yogyakarta 27 Mei 2006

Return merupakan hasil dari suatu investasi. Dalam dunia saham return dibagi menjadi dua unsur yaitu capital gain dan dividen. Capital gain merupakan selisih dari harga jual dan harga beli. Dividen merupakan laba yang dibagikan perusahaan kepada pemegang saham. Dalam penelitian ini unsur dividen diabaikan karena investor diasumsikan melakukan investasi dalam jangka pendek.

Abnormal Return adalah selisih antara return yang sesungguhnya terjadi (actual return) dengan return yang diharapkan (expected return). (Jogiyanto,2000:434). Abnormal Return digunakan untuk menguji kandungan informasi dari suatu peristiwa dengan 
cara melihat perilaku pasar. Reaksi pelaku pasar ditunjukkan dengan adanya perubahan harga sekuritas yang bersangkutan di sekitar tanggal peristiwa.

Dalam analisis diketahui bahwa tidak ada perbedaan antara abnormal return sebelum dengan sesudah terjadinya peristiwa gempa di Yogyakarta 27 Mei 2006. Tidak signifikannya abnormal return ditunjukan pada rata-rata abnormal return yang tidak beda jauh antara rata-rata abnormal return sebelum dengan sesudah peristiwa gempa di Yogyakarta 27 Mei 2006.

Tidak signifikannya antara rata-rata abnormal return sebelum dengan sesudah peristiwa gempa di Yogyakarta 27 Mei 2006 karena gempa tersebut merupakan suatu peristiwa yang sifatnya tidak terduga. Jadi tidak ada investor yang memperoleh informasi yang lebih dari peristiwa ini atau dapat di katakan bahwa informasi tersebut tersebar secara simetris. Tersebarnya informasi yang simetris mengakibatkan tingkat ekspektasi para pelaku pasar terhadap return saham adalah sama. Dalam kondisi seperti ini pelaku pasar tidak bisa memperoleh keuntungan di atas normal. Hal ini sesuai dengan teori yang dikemukakan oleh Beaver dalam Jogianto (2000:287) yang menyatakan bahwa pasar adalah efisisen jika harga-harga sekuritas terjadi jika setiap orang mempunyai informasi yang sama. Dimana dalam kondisi pasar yang efisien investor tidak akan memeperoleh abnormal return atau excessive return. Jadi dapat dikatakan bahwa pasar modal Indonesia masih dalam keadaan pasar yang efisien meskipun terjadi gempa di Yogyakarta 27 Mei 2006 karena tidak ada pelaku pasar yang mampu mendapatkan keuntungan di atas normal dari peristiwa ini.

\section{Perbedaan Trading Volume Activity (TVA) Saham Sebelum dan Sesudah Peristiwa} Gempa di Yogyakarta 27 Mei 2006

Trading Volume Activity (TVA) merupakan instrumen yang dapat digunakan untuk mengetahui perilaku investor dengan menggunakan parameter pergerakan volume perdagangan di pasar. Perhitungan trading volume activity (TVA) saham dilakukan dengan membandingkan jumlah saham yang ditransaksikan pada periode tertentu dengan jumlah saham yang beredar pada perusahaan tersebut pada periode yang sama. Kegiatan perdagangan dalam volume yang sangat tinggi di suatu bursa akan ditafsirkan sebagai tanda pasar modal akan membaik (bullish). Peningkatan volume perdagangan dibarengi dengan peningkatan harga merupakan gejala yang makin kuat akan kondisi yang bullish. 
Dalam analisis diketahui bahwa tidak ada perbedaan antara trading volume activity (TVA) sebelum dengan sesudah terjadinya peristiwa gempa di Yogyakarta 27 Mei 2006. Hal ini ditunjukkan dari analisis uji t dimana diperoleh thitung sebesar 1,059 dengan nilai signifikansi 0,317. Tidak signifikannya trading volume activity juga ditunjukan pada rata-rata trading volume activity yang tidak beda jauh antara rata-rata trading volume activity sebelum dengan sesudah peristiwa gempa di Yogyakarta 27 Mei 2006. Rata-rata trading volume activity pada periode sebelum peristiwa lebih tinggi jika dibandingkan dengan Rata-rata trading volume activity pada periode sesudah peristiwa. Dimana rata-rata trading volume activity pada sebelum peristiwa sebesar 0,0025913 dan sesudah peristiwa sebesar 0,0014475 .

Tidak signifikannya antara trading volume activity (TVA) sebelum dengan sesudah peristiwa gempa diYogyakarta 27 Mei 2006 mengindikasikan bahwa investor lebih cenderung berhati-hati dalam melakukan transaksi jual/beli saham. Hal ini di tunjukkan oleh nilai rata-rata trading volume activity yang cenderung menurun setelah terjadinya peristiwa gempa di Yogyakarta 27 Mei 2006. Husnan (2001) menjelaskan bahwa kegiatan perdagangan dalam volume yang sangat tinggi di suatu bursa akan ditafsirkan sebagai tanda pasar modal akan membaik (bullish). Dalam penelitian ini dapat kita lihat bahwa pasar modal dalam keadaan yang lesu/kurang baik (bearish). Hal ini dapat dilihat dari rata-rata trading volume activity yang cenderung menurun setelah terjadinya peristiwa gempa di Yogyakarta 27 Mei 2006. Dalam kondisi seperti ini investor akan melakukan strategi wait and see sampai ada informasi positif yang dapat menggerakkan harga saham ke arah yang positif dan memberikan keuntungan.

\section{KESIMPULAN}

Peristiwa gempa di Yogyakarta 27 Mei 2007 adalah bencana besar yang menyebabkan banyak korban meninggal dunia dan luka-luka ditambah dengan rusaknya infrastruktur dan bangunan sehingga menyebabkan aktivitas perekonomian terganggu. Dengan adanya gempa di Yogyakarta diharapkan masyarakat sadar akan

pentingnya asuransi dan berbondong-bondong mengasuransikan harta bendanya bahkan jiwanya untuk di asuransikan demi menjaga suatu kerugian yang tidak pasti. Banyaknya masyarakat yang mengasuransikan harta bendanya akan membuat perusahaan asuransi menjadi lebih berkembang dan akan menarik jumlah permintaan 
saham perusahaan asuransi yang akan di tunjukkan dengan adanya perubahan pada abnormal return dan trading volume activity.

Peristiwa gempa di Yogyakarta 27 Mei 2006 karena gempa tersebut merupakan suatu peristiwa yang sifatnya tidak terduga. Jadi tidak ada investor yang memperoleh informasi yang lebih dari peristiwa ini atau dapat dikatakan bahwa informasi tersebut tersebar secara simetris. Tersebarnya informasi yang simetris mengakibatkan tingkat ekspektasi para pelaku pasar terhadap return saham adalah sama, hal ini menyebabkan tidak terdapat perbedaan yang signifikan rata-rata abnormal return saham perusahaan asuransi sebelum dan sesudah terjadinya gempa di Yogyakarya 27 Mei 2006.

Pergerakan rata-rata trading volume activity 10 sebelum terjadinya gempa di Yogyakarta 27 Mei 2006 adalah fluktuatif dimana rata-rata trading volume activity pada periode sebelum peristiwa lebih tinggi jika di bandingkan dengan rata-rata trading volume activity pada periode sesudah peristiwa. Tetapi hal tersebut juga tidak cukup untuk menyebabkan rata-rata trading volume activity (TVA) saham perusahaan asuransi sebelum dan sesudah terjadinya gempa di Yogyakarya 27 Mei 2006 menjadi berbeda. Tidak terdapat perbedaan yang signifikan dikarenakan investor cenderung berhati-hati dalam melakukan transaksi jual atau beli saham sehingga mengakibatkan investor lebih memilih strategi wait and see.

\section{Saran}

Peneliti menyadari bahwa hasil penelitian ini masih jauh dari kesempurnaan, karena adanya berbagai keterbatasan baik dari segi alat analisis, ruang lingkup, populasi dan sampel. Oleh karena itu peneliti menyarankan: (1) Dalam berinvestasi saham, investor hendaknya mengetahui terlebih dahulu faktor-faktor apa saja yang dapat menyebabkan perubahan harga saham; (2) Investor hendaknya tidak terlalu terburu-buru dalam melakukan aksi jual atau beli saham dikarenakan suatu peristiwa tertentu. Karena suatu peristiwa belum tentu mempengaruhi harga saham; (3) Investor yang tidak mempunyai informasi privat hendaknya selalu mengamati perubahan harga saham karena perubahan harga saham merupakan refleksi dari investor yang mempunyai informasi privat tersebut; (4) Penelitian ini menggunakan market adjusted model dalam menghitung expected return, untuk penelitian selanjutnya diharapkan menggunakan model yang lain agar hasil penelitian dapat 
diperbandingkan; (5) Sampel yang di gunakan dalam penelitian ini hanya saham perusahaan asuransi, untuk peneliti selanjutnya diharapkan menggunakan sampel yang mencakup seluruh sektor; (6) penelitian selanjutnya diharapkan menggunakan uji yang lain agar hasil penelitian dapat diperbandingkan.

\section{DAFTAR PUSTAKA}

Husnan, Suad. 2001. Dasar-dasar Teori Portofolio dan Analisis Sekuritas. Edisi Ketiga. Yogyakarta: Unit Penerbit dan Percetakan AMP YKPN.

Jogiyanto. 2000. Teori Portofolio dan Analisis Investasi. Edisi Ketiga. Yogyakarta: BPFE UGM.

Subagyo. 2005. Pengaruh Kenaikan BBM terhadap Return, Abnormal Return, Trading Volume Activity, dan Security Return Variability pada Perusahaan Pertambangan Minyak dan Gas Bumi. Jurnal Ekonomi dan Bisnis Indonesia.

Suryawijaya, Marwan A \& Setiawan faizal A. 1998. Reaksi Pasar Modal Indonesia terhadap Peristiwa Politik dalam Negeri ( Event Study Pada 27 Juli 1996). Kelola Gajah Mada University Bussiness Reviem. VII (18) 137-155.

\footnotetext{
*) Lulu Nurul Istanti, SE., MM., Dosen Fakultas Ekonomi Universitas Negeri Malang
} 